\title{
sciendo
}

DOI: $10.2478 /$ jolace-2021-0004

\section{The positive benefits of the practical application of the simulation software}

\author{
Renáta Machová, Lilla Fehér, Enikő Korcsmáros, Zsuzsanna Gódány, \\ Silvia Tóbiás Kosár, Erika Seres Huszárik \\ János Selye University, Slovakia \\ machovar@ujs.sk
}

\begin{abstract}
The research, related to innovation has been in a focus of academics for a long time. In the current study, the authors present the positive benefits of applying an innovative teaching method, based on primary research, applying a questionnaire-based survey. They targeted to examine how a business simulation software modifies the labour market efficiency of university students. The respondents consider themselves to be least competitive in terms of self-confidence and an initiative ability. Both skills can be developed as a result of the application of the business simulation software.
\end{abstract}

Keywords: innovation, different generations, playful learning, labour market efficiency

\section{Introduction}

Currently we are being faced by constant change, which is accompanied with innovation in different fields of our life. The term "innovation" is associated with the name of Schumpeter in historical context. He defined innovation as a process, which starts with a creative idea that can be implemented into practice. Since our research is focusing on innovation applied in education, we will introduce the theoretical background of the issue in this context. Our study will present the difference between the generations and their characteristics, as well as their position on the labour market. One of the biggest challenges of the corporate sector is the coordination of cooperation and working methods of these generations. The focus shifts on online activity of the younger generation and their commitment to IT tools. In contrast to emphasizing the negative impact of the above-mentioned tools, the authors will introduce the positive, labour market enhancing use of innovative teaching methods.

\section{Innovative teaching methods}

Innovation is also present in the education, which contributes to efficiency of education, supports the teacher in work and enables them to apply different methods of knowledge transfer, as well as provides students with an opportunity to try new methods of acquiring knowledge. Since the students participating in education process are different, the use of different methods in the education process can lead to selection of the most effective methods to be applied in the education process. Szőköl (2018), Falus (2001), Radnóti (2006), Hunya (2009; 2010) and Fejes (2013) examined the teaching methods used on individual lessons. All the findings prove that applying innovative methods to support learning are still rare. Instead, traditional teaching methods dominate. The innovative teaching methods may significantly change the traditional lessons; lectures are a time-consuming activity. It is interesting that mostly the older teachers are open to experimenting in teaching methods. According to Radnóti (2016), the reason might be that young teachers have little experience and insist on methods they 
have experience with from their university years (Czakó et al., 2017). Daruka and Csillik (2015) targeted the issue of teacher training in the field of Economics. They came to conclusion that the given qualification consists of gaining theoretical knowledge, while development of skills and competencies lacks behind. It is mostly about independent thinking, understanding different approaches, interpretive and critical attitudes, shortterm and long-term impact of decisions that appear at a certain level and quality of professional training (Máté \& Kiss. 2017). Certain skills and competencies are not addressed adequately e. g. respecting the rules, conflict resolution (value and interest), consideration and understanding of different approaches, development of culture of discussion, competition, educational attitudes supporting learning. They came to conclusion that the teachers of Economics are not sufficiently trained to develop certain skills because they themselves do not receive adequate training in teacher education (Czakó et al., 2017). According to Makó (2015), the low professional qualification and the weak general knowledge threaten the competitiveness in any segment of the labour market. The skills that the students have learned at university, will be utilized to build their currently non-existing professional career in the future. Students have to acquire critical thinking, social and ethical responsibility in order to become the future world leaders or valuable citizens. Students have to learn skills that will prepare them for successful life in the modern world. It is important that students:

- understand the deep conceptual background of the chosen discipline,

- learn to be able to work effectively in mixed teams,

- approach challenges with curiosity, develop critical thinking and creativity,

- use their skills in innovative way to solve complex problems,

- understand and respect different cultures and perspectives,

- thrive effectively and independently in their profession,

- become charismatic individuals both personally and professionally.

In almost all areas of our lives - work, technology and the environment there is an accelerated change, which places new requirements on university students. They have to be prepared for the future, be prepared to deal with complex multidisciplinary problems, be able to present new perspectives on global challenges and be motivated to become leaders in their professional field (Schwab, 2016).

Tertiary education in the $21^{\text {st }}$ century is more than just gaining knowledge in a single discipline. The skills, such as critical thinking, creative problem-solving, teamwork and communication have become valuable skills. The amount of data and information has multiplied, and therefore navigation, selection, critical evaluation and decision-making skills are essential to succeed in the modern society. Modern tertiary education is no longer about the transfer of information. Students should be taught to interpret concepts, facts, ideas, how to think and act professionally, and how to master valuable knowledge and findings essential in the society.

Significant is the research conducted by Deslauriers, Schelew and Wieman (2011), where the results clearly present that traditional lecture-oriented education does not deliver the desired results in terms of acquiring key skills of the $21^{\text {st }}$ century. Educational techniques that are more interactive and allow students to participate on lectures, will result in strengthening their personal and professional identity, support learning and strengthen social feelings. As a positive outcome, they will be more goal-oriented not only in the classroom, but in practical life as well (Holmes, Wieman, \& Bonn, 2015). According to Freeman et al. (2014), the active learning methods increase the effectiveness of education by providing a deeper understanding of concepts. According to Talbota et al. 
(2106), the transition to active education allows students to spend most of their time in classroom with activities requiring collection of wide range of information. This can be achieved by applying different methods, e.g. using electronic appliances, answering questions, filling out form, examining a problem, discussion with other students. The strategy of education should include the following aspects:

- guided preparation for lessons,

- time for reflection,

- applying mixed teaching techniques,

- increased emphasis on applying knowledge,

- the "importance" of incorrect answer,

- the need for different measurement methods.

The results of various research show that active education improves the educational process by applying several starting points for the students (Deslauriers, Schelew, \& Wieman, 2011; Freeman et al., 2014; Rozsa, 2018).

\section{Generations on the labour market}

Currently, there are representatives of several generations on the labour market, which can be clearly identified on the basis of predefined specifics (demographic data, attitude, work experience, etc.). Recognition of the characteristics of individual groups is essential in terms of the company success, as it is important to create harmonious working environment and relationship based on mutual trust, equality and determination (Tej, Vagaš, \& Miško, 2019).

If the new generation actively enters the labour market (around the year 2020), a labour market is created, where members of five different generations will be present. This fact is a great challenge for organizations since it is crucial to approach different generations, to be able to address and utilize the different values and expectations of these generations.

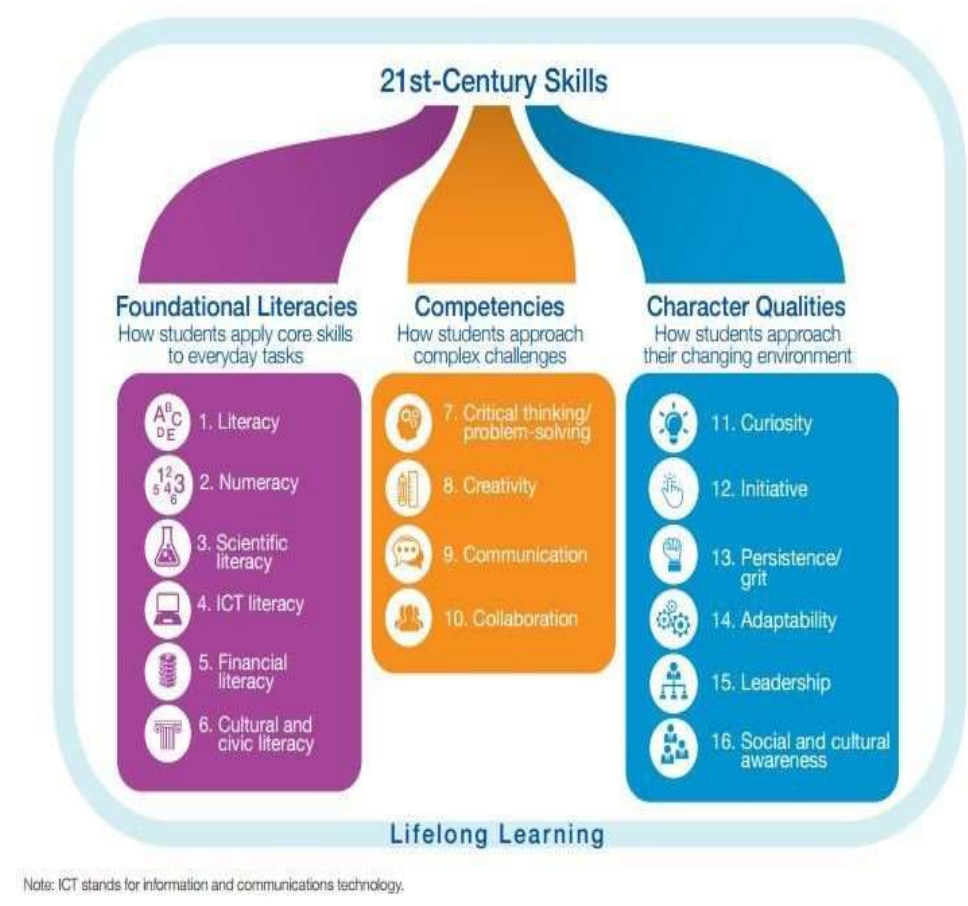

Figure 1: Key skills on the labour market in the $21^{\text {st }}$ century (source: WEF, 2016, online) 
Technological skills are the most essential on the $21^{\text {st }}$ century labour market. Most of the skills on the global labour market are interconnected. The basic managerial skills are the following: cooperation and teamwork, creativity and imagination, critical thinking, problem-solving, flexibility, cultural awareness, information literacy, technological and civic literacy, social responsibility and ethics.

It is important to understand the motivation of different generations, but also necessary to understand the differences. As a manager, it is important to motivate each of the employees to work effectively and support to develop their strengths. The following figure shows several options for managing multigenerational workplaces.

Several analyses show a growing gap between the theoretical knowledge and the practical experience. The required skills (that can be developed within the framework of gamification) include the following 16 key competencies of the individual, which help them to find job on the labour market.

\section{Gamification and its use in education}

We can often hear from the members of older generation how different the representatives of younger generation are. We can conclude that each generation is somewhat different from the previous one, which is also influenced by the environment of the individual. This fact is not different even in the age of accelerated flow of information. The development of information technology has impact on the students currently entering the university education, and will have even bigger impact on children.

Playful education has been a part of pedagogy for a long time, games with educational purpose appeared quite early. When introducing game, game elements and techniques are used, but the goal is not the play itself, but the increase of interest and efficiency (Rigóczki, 2016; Zichermann \& Cunningham, 2011).

Gamification tools in education can be used to raise awareness and increase motivation. According to Kenéz (2016), gamification can be used in all subjects and courses, in case of any topic and technical conditions, with any number of students. The introduction of game is a system application, which requires planning. According to Werbach and Hunter (2012), it is important to start with certain goals. All the tools and goals work properly, if the players have good experience, pleasure and are motivated by the game.

The goals can focus on the lesson (higher participation of students, attention, commitment), work from home, continuity of education - which seems to be the most problematic. It is advised to choose one goal first, and make it a measurable factor for comparison (Kenéz, 2016).

Similarly, as gamification is present in development of the individual or group, we can recognize it in other areas of life. For us as teachers, it is necessary to be informed what kind of opportunities we have in the system of formal education, and where game can be introduced to students (Kenéz, 2016).

Game and game elements are part of our life. It does not depend what stage of intellectual development children are, they are in contact with toys. Conscious parents select the appropriate toys for their children, which contribute to quick development of their skills.

If we intend to define "gamification ", it is necessary to mention Huizinga, who already stated in 1944 that in the evolution of humanity we entered the phase of "homo ludens" Man the Player. In this era, the game plays a major role in the human culture. Play elements gradually cover all the aspects of our life. Huizinga defined the term "play" as follows: 
"Play as a free activity standing quite consciously outside 'ordinary' life as being 'not serious' but at the same time absorbing the player intensely and utterly. It proceeds within its own proper boundaries of time and space, according to fixed rules and in an orderly manner" (Huizinga, 1944, p. 14).

It is important to note that the definition provided by Huizinga draws the attention to the fact that the play must be performed according to certain rules. According to Zichermann and Linder (2013, p. 115), a broader interpretation of the term is "play is considered to be any activity that brings pleasure and relax".

In addition to these definitions, many philosophers and sociologists provided their own definition of play, but the easiest way to define "play" is as an activity that has no direct purpose only to entertain and ensure the feeling of freedom (Zelenková \& Hanesová, 2019).

There are many similarities between the serious game and the game defined in the previous paragraphs, but there is a fundamental difference between the serious game and game. While the main purpose of the game is entertainment, in the case of serious game it has only a secondary function. The main purpose of serious game is to facilitate the learning process, as well as it can be applied in different fields of life. In addition to education it can be also used in the field of industry, military, medicine, religion and politics. Serious game is a part of gamification, but it is not a necessary condition for gamification (Pacsi-Szabó, 2017; Deterding et al., 2011).

\section{Results of empirical research}

The aim of the research is to map the experience related to practical use of the simulation software as an innovative teaching method. To achieve our goal, we conducted primary research in the form of a questionnaire survey. The questionnaire was completed anonymously in October 2019 and February 2020. Evaluating sampling as a form of nonrandom sampling was applied, the selection of elements is based on the researcher's decision. There were collected 256 questionnaires that could be evaluated before application of the simulation software, 236 questionnaires were evaluated after the application of the software. We used SPSS to analyse the obtained data.

To achieve the research goals, the research questions were outlined:

1. How do people who have already used/have not used simulation software during their education evaluate the labour market efficiency of this tool? How did the opinion of the respondents change who used the simulation software?

2. Is it possible to form different groups based on playful interaction among the students?

In addition to univariate analyses, e.g. mean, mode, standard deviation, which provide an insight into the opinion of the respondents, we also applied multivariate analysis for deeper analysis of the obtained data. In this research the cluster analysis will be highlighted. The main objective was to obtain detailed information about the individuals forming certain groups. The Ward-method, as a hierarchical method was used for cluster analysis.

$$
d_{\text {Ward }}\left(C_{i}, C_{j}\right)=\sum_{u, v \in C_{i} \cup C_{j}} d^{2}(u, v)-\left(\sum_{u, v \in C_{i}} d^{2}(u, v)+\sum_{u, v \in C_{j}} d^{2}(u, v)\right)
$$

Using the Ward's method, we can minimize the squares within the clusters, and merge the two clusters that cause the lowest square error increase (Fogaras \& Lukács, 2005). Within the clusters we conducted the cluster table analysis related to gender, place of 
residence and generation group of the respondents. The further relationship between the factors was examined using a Chi-Square test and Cramer V.

Our first research question examined how individuals who already had as well as have not had experience with simulation software in their educational process can measure their efficiency on the labour market. We also examined how the opinion of these groups changed after using the simulation software. At first, we examined the entire sample, how the respondents feel about their efficiency on the labour market. To perform the analysis, the mean, mode and standard deviation indicators were taken into account. In the case of 12 statements examining labour market efficiency on Likert scale, 3 of the statements achieved lower average, so the respondents rather agreed with the statements than not. The most positive opinion was expressed to the statement "I take responsibility for my actions"(4.4). This was followed by the statement about independent and determined decision-making (4.2), and the statement about commitment to further development (4.1). In terms of responsibility, there is less agreement among the members of Generation Y. In this case we experienced the largest deviation from 1. The least positive our respondents were regarding the initiative ability (3.00) and the appropriate level of self-confidence (3.3). These are the skills that need development among the students. As a benefit of the simulation software, we should mention that the mentioned competencies can be developed with the help of the software applied in the education process. As for the competence of initiative, generation $Y$ expressed even more negative opinion than the younger generation. The group average remained under the value of 3 . Positive opinion about self-confidence was provided by male respondents. A deeper analysis of Generation $Y$ shows that apart from the statement about self-confidence, women tend to have more positive opinion, consider themselves more valuable on the labour market, while in the case of Generation Z, the male respondents expressed more positive opinion.

As a next step, we will continue by answering the first half of our research question. The following table summarises the results.

\begin{tabular}{|lllllll|}
\hline \multicolumn{1}{c}{$\begin{array}{c}\text { Primary } \\
\text { education }\end{array}$} & yes & no & yes & no & yes & no \\
\hline & 4.3 & 3.8 & 4 & 3.8 & 3.9 & 3.8 \\
\hline I am good at problem-solving. & 4 & 3.9 & 3.9 & 3.9 & 3.4 & 4 \\
\hline I do my job independently and accurately. & 3.7 & 2.9 & 3.1 & 2.9 & 3.6 & 2.9 \\
\hline I have a high degree of initiative. & 4.3 & 3.7 & 3.9 & 3.6 & 4.4 & 3.5 \\
\hline I can co-operate with others in team. & 4 & 4.1 & 3.9 & 4.1 & 4.3 & 4.1 \\
\hline I am committed to my further development. & 4.7 & 4.4 & 4.4 & 4.4 & 4.7 & 4.4 \\
\hline I take responsibility for my actions. & 4.3 & 4.2 & 4.5 & 4.1 & 4.6 & 4.1 \\
\hline $\begin{array}{l}\text { I am decisive and can make decisions on my } \\
\text { own. }\end{array}$ & 4.7 & 3.9 & 4.1 & 3.9 & 4.9 & 3.8 \\
\hline I am open to change. & 3 & 3.3 & 3.6 & 3.3 & 3.9 & 3.3 \\
\hline I have an adequate level of self-confidence. & 4 & 3.7 & 4 & 3.7 & 4.3 & 3.7 \\
\hline $\begin{array}{l}\text { I can easily process the information I } \\
\text { receive. }\end{array}$ & & & & & & \\
\hline I find easily understand myself face-to-face. & 4 & 3.7 & 3.9 & 3.7 & 4.4 & 3.6 \\
\hline $\begin{array}{l}\text { I respond flexibly to the changes of the } \\
\text { environment. }\end{array}$ & 4 & 3.6 & 3.8 & 3.6 & 4 & 3.6 \\
\hline
\end{tabular}

Tab. 1: Assessing labour market efficiency by those having and not having experience with a simulation software 
Based on the obtained results, in almost all cases the respondents who have already had experience with a stimulation software at any stage of their education, expressed positive opinion about their efficiency entering the labour market. The results of our research support our preliminary expectations that using simulation softwares in the education process has importance and benefits. The students became better in problemsolving, developed and ability to do their work independently and accurately, use their initiative, good at teamwork, take on responsibility for their actions, feel free to make decisions, open to changes, developed enough self-confidence, have an ability to process the information they receive, get on well with their environment and respond flexibly to changes. In the case of "commitment to further development” there is no change in behaviour when applying the software.

In order to answer the second half of the fifth research question, the averages had to be also compared. The same 12 statements that we have analysed before applying the software, the students were asked after applying the software. The obtained results are presented in the figure below.

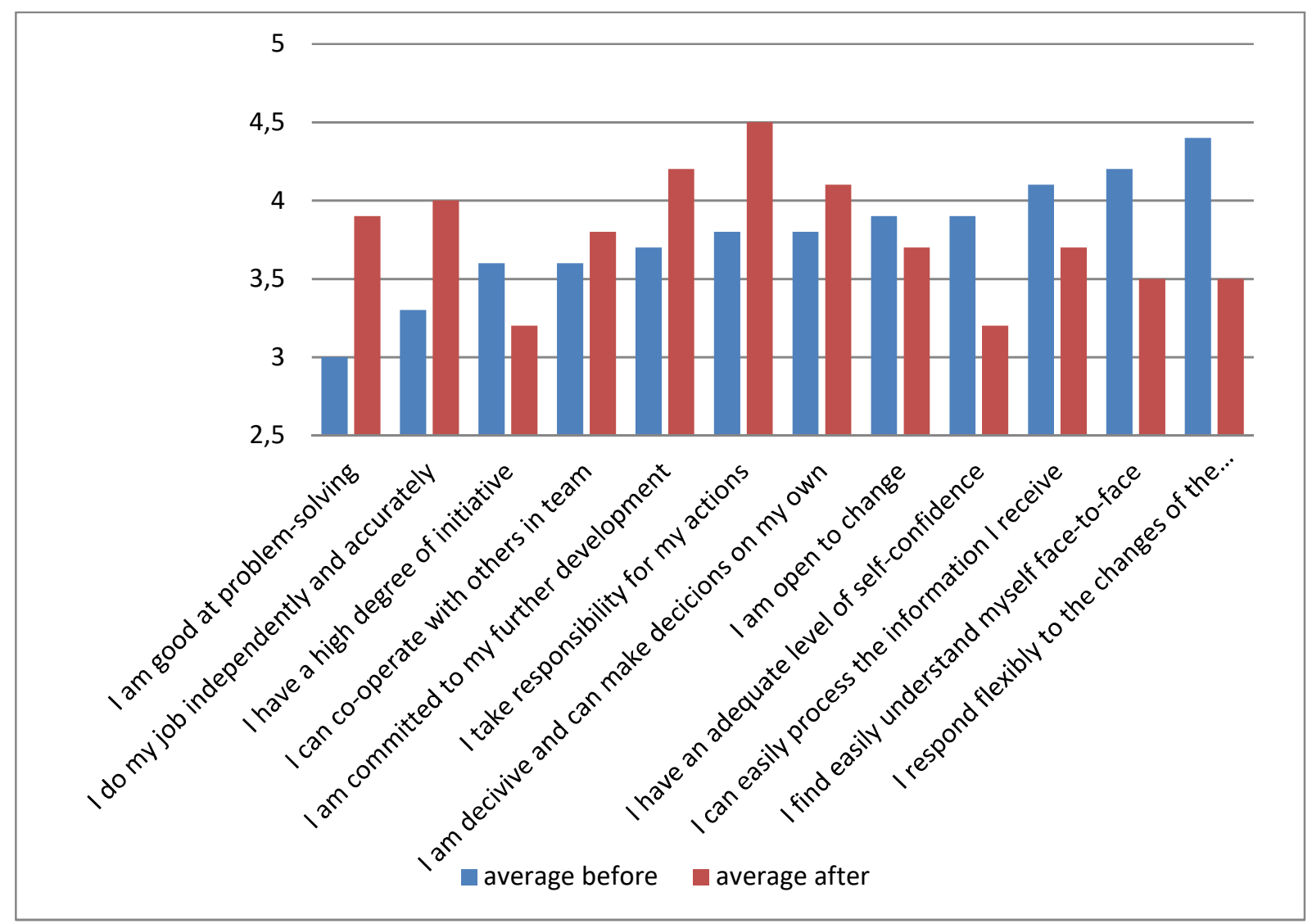

Figure 2: Assessing labour market efficiency before and after applying the simulation software

The figure above shows that the application of simulation has improved vs worsened the efficiency of the graduates on the labour market in 50/50. The initiative ability and the self-confidence of the students have increased significantly, which gained the lowest average in the previous research showing the average of 3 and 3.3. Positive change can be detected in the improvement of problem-solving ability and the oral communication. There is only a small change or improvement in the flexibility of responding to 
environmental challenges and processing the obtained information. Negative change after applying the software was detected in the case of 6 factors. Students assessed themselves worse in terms of responsibility, independent and determined decision-making, and openness to change than before applying the method. Small but negative change can be detected in terms of teamwork, commitment to self-development and the independent, accurate work. Summarizing the outputs, we can find positive the improvement of the two weakest characteristics of the students, the initiative and the self-confidence, which are the key factors of the competitive labour market. It is difficult to imagine a success without the existence of the mentioned skills.

The second research question focused on creating different groups of students based on the assessment of playful learning. In order to answer the question, a cluster analysis was used in the SPSS system. The aim of the method is to arrange the observation units into a homogeneous group based on the variables involved in the analysis. The process of cluster analysis was started by defining the problem and formulating the research question. The last question of the questionnaire was relevant following the application of the software, as we wanted to organize our students into groups based on these 14 statements. Before running the cluster analysis, it is necessary to examine the conditions of the analysis. There was no need to standardize the data, as our variables were measured on a five-point metric scale, and no flagrant elements were detected. The correlation between the variables was not too high either, so clustering was made possible. Since our variables are measured on a metric scale, two observation units can be considered similar, when the distance between them is small, and they are the same if the distance between them equals to zero. The Euclidean distance was used to measure the distance. The next step of the cluster analysis is to select the cluster method to be applied. There are two methods of clustering. We can differentiate the hierarchical and non-hierarchical cluster formation. Decision about which method is more appropriate is not an easy task. According to professional recommendation, it is advisable to use the methods together. The ideal number of clusters was determined by using the Wardtechnique as a hierarchical method.

To determine the number of clusters, we examined the aggregation algorithm and the dendogram, based on which both the two- and three-cluster solutions required further examination. The three-cluster and two-cluster solutions resulted in groups of almost the same homogeneity, but in the case of the two-cluster solution the standard deviation of our first cluster improved, so finally decided on two-cluster solution. $66 \%$ of the students were classified to Cluster 1, while $34 \%$ were classified to Cluster 2 . The clusters were named and characterized based on the answers of respondents provided for statements about playful learning.

The first cluster is formed by 156 students, who do not really enjoy the opportunity of competition provided by game. The reward is not really motivating for them, and they get angry easily, when they cannot solve the task. There negative and positive emotions during the game are not outrageous either. Based on the values presented in the table above, this gorup enjoyed the application of simulation software less, the game rather brought negative attitudes to the surface, so this group is called the „uninterested negatives". The teacher has a key role to play raising the students' awareness on playful learning, motivating them to compete, and applying tools to raise interest of the students in playful learning.

Cluster 2 is formed by a smaller group of students. There are 80 students in the cluster, which forms $34 \%$ of the sample. They enjoy competition, the opportunity to integrate their knowledge gained by studying different subjects, and they want to prove their 
abilities. They will not get angry if cannot solve tasks as well as the tasks to be solved do not generate negative feelings. It is benefiting to focus the attention of students on competition, reward and new challenges. This cluster is formed by the „competing positives”. Statistical testing of average differences is essential. An independent sample ttest was used for testing. After performing the independent sample t-test, we found that the opinion of our two clusters differs significantly for all statements.

\section{Conclusion}

The aim of the present research was to map the assessment of the labour market efficiency of the university students in terms of applying playful teaching methods. Our respondents considered their labour market efficiency rather positive, more positivity can be detected among the representatives of Generation Z, while with the older generation $(\mathrm{Y})$ rather the female respondents, in the case of younger generation $(\mathrm{Z})$ rather the male respondents assessed their labour market position positive. As a further significant experience with the software we can summarize that self-assesment of students regarding the skills addressed has significantly improved, which means that simulation softwares fulfill the expectations in the education system, since they can improve the initiative and the self-confidence of the students. The most important conclusions of our cluster analysis is that it is more difficult for the older generation respondents to open to technological challenges. They were more sceptical about application of the software in the education process, so the role of the teacher is to motivate them to accept the new methods of teaching. In contrast, the representatives of younger generation are open to new methods applied in the education process, it is worth to put emphasis on competition, which can be defined as a strong labour market competence. Based on the obtained research results, we can assume that the novel methods in education play an essential role in the Slovak education system, as they result in strengthening labour market competencies among the members of young generation.

\section{Acknowledgements}

The scientific article is a partial output from the KEGA project 005UJS-4/2019 entitled "Streamlining Managerial Sills of the generations $\mathrm{Z}$ and $\mathrm{Y}$ by gamification on the context of linking science and practice", which is solved at the Faculty of Economics of the J. Selye University in Komárno.

\section{References:}

Czakó, Á., Gyori, Á., Schmidt, L., Boros, I. ifj. (2017). Innovatív pedagógiai módszerek a szakmai oktatásban. A szakmai tanárok módszerei szociológiai megközelítésben. In: Socio.hu, 7(2), 1-21. DOI: 10.18030/socio.hu.2017.2.1

Daruka, M. \& Csillik, O. (2015). Horizontális pedagógiai elemekhez kapcsolódó modellajánlások kidolgozása a gazdasági és pénzügyi nevelés terén. Budapest: Oktatáskutató és Fejlesztő Intézet.

Deslauriers, L., Schelew, E., \& Wieman, C. (2011). Improved Learning in a LargeEnrollment Physics Class. Science, 332(6031), 862-864. DOI: $10.1126 /$ science.1201783

Deterding, S. et al. (2011). Gamification: Using game-design elements in nongaming contexts. In CHI'11 Extended Abstracts on Human Factors in Computing Systems, 24252428. DOI:10.1145/1979742.1979575

Falus, I. (2001). Az oktatási módszerek kiválasztására és alkalmazására vonatkozó módszerek. In: A pedagógusok pedagógiája. Budapest: Nemzeti Tankönyvkiadó. 
Fejes, J. B. (2013). A tanulási környezet motivációs szempontú vizsgálata a célelmélet alapján felső tagozatos tanulók körében. Iskolakultúra, 23(11), 44-57.

Fogaras, D., Lukács, A. (2005). Klaszterezés. (Clustering). Informatikai algoritmusok II. 29. Fejezet. ELTE, Budapest, 1395-1435. Available on: http://web.cs.elte.hu/ lukacs/Papers/klaszterezes.pdf

Freeman, S., Eddy, S. L., McDonough, M., Smith, M. K., Okoroafor, N., Jordt, H., \& Wenderoth, M. P. (2014). Active learning increases student performance in science, engineering, and mathematics. In: Proceedings of the National Academy of Sciences of the United States of America, 111(23), 8410-8415. Available on: https://doi.org/10.1073/pnas.1319030111

Holmes, N. G., Wieman, C. E., \& Bonn, D. A. (2015). Teaching critical thinking. In: Proceedings of the National Academy of Sciences of the United States of America, 112(36), 11199-11204. Available on: https://doi.org/10.1073/pnas.1505329112

Huizinga, J., \& Máthé, K. (1944). Homo ludens: kísérlet a kultúra játék-elemeinek meghatározására. Budapest: Athenaeum.

Hunya, M. (2009). Projektmódszer a 21. században I. Új Pedagógiai Szemle, 59(11), 7596.

Hunya, M. (2010). Projektmódszer a 21. században II. Új Pedagógiai Szemle, 60(1-2), 75 96.

Kenéz, A. (2016) A játékosítás (gamification) a felsőoktatásban Debreceni Egyeten Gazdaságtudományi Kar. Debrecen.

Máté, D., \& Kiss, Z. (2017). An assessment of financial knowledge in higher education. Acta Oeconomica Universitatis Selye, 6(1), 83 - 98.

Makó, Á. (2015). A szakképzett pályakezdők munkaerő-piaci helyzete és elhelyezkedési esélyei. Közgazdasági Szemle, 62(5), 502-524.

Pacsi, D., \& Szabó, Z. (2017). A gamifikáció fejlődése és a magyar gamifikációs trend alakulása. Studia Mundi - Economica, 4(1), 57-68.

Radnóti, K. (2006) Milyen oktatási és értékelési módszereket alkalmaznak a pedagógusok a mai magyar iskolában? In: Hidak a tantárgyak között (pp. 131-167). Budapest: Országos Közoktatási Intézet.

Rigóczki, Cs. (2016). Gyönyörűségnek társa legyen a hasznosság - Gamifikáció és Pedagógia. Új Pedagógiai Szemle. 66(3-4), 69-75.

Rozsa, Z. (2018). Ghostwriting among business management students. Acta Oeconomica Universitatis Selye, 7(2), 151 - 161.

Schwab, K. (2016). The Fourth Industrial Revolution: what it means and how to respond. Webforum. Available on: https://www.weforum.org/agenda/2016/01/the-fourthindustrial-revolution-what-it-means-and-how-to-respond/

Szokol, I. (2018). Continuous Improvement of the Teaching Process in Primary Education. Journal of Language and Cultural Education, 6(1), 53-64. DOI 10.2478/jolace-20180004.

Talbot, R. M. I., Doughty, L., Nasim, A., Hartley, L., Le, P., Kramer, L. H., Kornreich-Leshem, H., Boyer, J. (2016). Theoretically Framing a Complex Phenomenon: Student Success in Large Enrollment Active Learning Courses. Physics Education 2016. DOI: 10.1119/perc.2016.pr.081

Werbach, K., \& Hunter, D. (2012). For the win: How Game Thinking Can Revolutionize Your Business. Wharton, Philadelphia.

Zelenková, A., \& Hanesová, D. (2019). Intercultural competence of university teachers: a challenge of internationalization. Journal of Language and Cultural Education, 7(1), 118. DOI: $10.2478 /$ jolace-2019-0001 
Zichermann, G., \& Cunningham, C. (2011). Gamification by Design - Implementing Game Mechanics in Web and Mobile Apps. Sebastopol: O'Reilly Media. Available on: http://storage.libre.life/Gamification_by_Design.pdf

Zichermann, G., \& Linder, J. (2013). The Gamification Revolution: How Leaders Leverage Game Mechanics to Crush the Competition. McGraw-Hill.

\section{Contact}

Dr. habil. Ing. Renáta Machová, PhD.

János Selye University

Faculty of Economics and Informatics

Bratislavská cesta 3322

94501 Komárno

Slovakia

machovar@ujs.sk 